\title{
IMPLEMENTASI SISTEM INFORMASI MANAJEMEN NIKAH GANDA: STUDI KEBIJAKAN STRATEGIS TRANSFORMATIF DAN EFEKTIVITAS HUKUM
}

\author{
Ahmad Arif Masdar Hilmy dan Neila Sakinah \\ Qur'an Center Gresik. Email: arivmasdar@gmail.com
}

\begin{abstract}
The web-based Marriage Management Information System (SIMKAH) is a new system that is used in the Office of Religious Affairs (KUA) Districts throughout Indonesia, replacing the desktop-based SIMKAH. Although Regulation No. 20 of 2019 regarding Marriage Registration has been passed to fully switch to web-based SIMKAH, the KUA of Gaynngan, Surabaya, instead chose to implement Dual SIMKAH, which is web and desktop based. This article aims to find out the description and implementation of Dual SIMKAH in KUA of Gayungan, as well as a review of transformative strategic policies and legal effectiveness on the implementation of the Dual SIMKAH. This field research uses descriptive qualitative methods. Data mining is done through in-depth observation and interviews, as well as hands-on experience so that goals can be realized. This study produces several conclusions: (1) the implementation of Dual SIMKAH is very much needed as an anticipative effort when web-based SIMKAH experiences problems, especially in server repair, (2) the implementation of Dual SIMKAH can be assessed as a transformative strategic policy, (3) at the technical level, implementation Web-based SIMKAH still contains various problems, such as the application of Dual SIMKAH which has more support, old habits that are still inherent, the absence of announcements when the server will be repaired, and social conditions that make it impossible to switch completely to web-based SIMKAH.
\end{abstract}

Keywords: SIMKAH, KUA, Marriage Registration

Abstrak: Sistem Informasi Manajemen Nikah (SIMKAH) berbasis web
merupakan sistem baru yang digunakan di Kantor Urusan Agama (KUA)
Kecamatan seluruh Indonesia, menggantikan SIMKAH berbasis desktop.
Meskipun Peraturan Nomor 20 Tahun 2019 tentang Pencatatan
Perkawinan telah disahkan agar beralih sepenuhnya ke SIMKAH berbasis
web, namun KUA Gayungan Kota Surabaya justru memilih untuk
menerapkan SIMKAH Ganda, yakni berbasis web dan desktop. Artikel ini
bertujuan untuk mengetahui deskripsi dan implementasi SIMKAH Ganda
di KUA Gayungan, serta tinjauan kebijakan strategis transformatif dan
efektivitas hukum terhadap implementasi SIMKAH Ganda tersebut.
Penelitian lapangan ini menggunakan metode deskriptif kualitatif.
Penggalian data dilakukan dengan observasi dan wawancara secara
mendalam, serta praktik secara pengalaman supaya tujuan dapat terwujud.

AL-HUKAMA

The Indonesian Journal of Islamic Family Law

Volume 09, Nomor 02, Desember 2019; ISSN:2089-7480 
Ahmad Arif Masdar Hilmy dan Neila Sakinah: Implementasi......

Penelitian ini menghasilkan beberapa kesimpulan: (1) implementasi SIMKAH Ganda sangat diperlukan sebagai upaya antisipasi saat SIMKAH berbasis web mengalami permasalahan, khususnya dalam perbaikan server, (2) implementasi SIMKAH Ganda dapat dinilai sebagai kebijakan strategis transformatif, (3) pada tataran teknis, implementasi SIMKAH berbasis web masih mengandung berbagai permasalahan, seperti penerapan SIMKAH Ganda yang lebih mendapat dukungan, kebiasaan lama yang masih melekat, tidak adanya pengumuman saat server akan diperbaiki, serta kondisi-kondisi sosial yang tidak memungkinkan untuk beralih sepenuhnya ke SIMKAH berbasis web.

Key words: SIMKAH, KUA, Pencatatan Perkawinan

\section{Pendahuluan}

Dalam Pasal 1 Undang-undang No. 1 Tahun 1974 tentang Perkawinan (UUP) dinyatakan bahwa perkawinan ialah ikatan lahir bathin antara seorang laki-laki dan seorang perempuan dengan tujuan membentuk keluarga bahagia yang kekal berdasarkan Ketuhanan Yang Maha Esa. Tujuan tersebut dapat terwujud bilamana perkawinan telah memenuhi syarat-syarat, baik yang diatur dalam hukum materiil maupun formil di Indonesia. Lebih lanjut dalam Pasal 2 UUP disebutkan bahwa tiap-tiap perkawinan dicatat menurut peraturan perundang-undangan yang berlaku.1

Dalam bidang perkawinan, permasalahan yang terjadi di masyarakat semakin kompleks. Salah satu permasalahan yang semakin berkembang ialah dalam hal pencatatan perkawinan, mengingat perkawinan di Indonesia baru dianggap sah apabila sesuai dengan ketentuan hukum agama dan telah dicatatkan. Setiap warga Negara Indonesia yang beragama Islam, pencatatan perkawinannya dilakukan oleh Pegawai Pencatat Nikah di KUA. Pegawai tersebut berkewajiban mengawasi, menyaksikan dan melakukan pencatatan nikah. Pencatatan perkawinan sangatlah penting2, karena untuk

1 Undang-Undang No. 1 Tahun 1974 tentang Perkawinan, https://kemenag.go.id/file/dokumen/UUPerkawinan.pdf.

2 Pencatatan pernikahan adalah kegiatan menulis yang dilakukan oleh seseorang sebagai bentuk pengadministrasian mengenai suatu peristiwa pernikahan. Pasangan mempelai yang telah melakukan pencatatan nikah, maka ia akan mendapatkan perlindungan hukum sebab buku nikah yang diperolehnya merupakan bukti autentik tentang keabsahan pernikahan itu baik secara agama maupun Negara. Dengan buku nikah itu, mereka dapat membuktikan pula keturunan sah yang dihasilkan dari pernikahan tersebut dan memperoleh hak- 
mendapatkan perlindungan hukum bagi yang bersangkutan sesuai amanat PMA Nomor 19 Tahun 2018 tentang Pencatatan Perkawinan.3

Dalam pelaksanaan pencatatan perkawinan, hambatan yang kerap kali ditemui bila pencatatan dilakukan secara manual ialah sulitnya penelusuran status calon pengantin pada saat ia melakukan permohonan nikah dan juga ditemukan kasus adanya pernikahan kedua dari calon pengantin yang tidak diketahui bahwa sebelumnya ia telah menikah. Hingga pada Tahun 2006, Bimbingan Masyarakat (Bimas) Islam berusaha mewujudkan pelayanan administrasi berbasis teknologi melalui Sistem Informasi Manajemen Nikah (SIMKAH) pada KUA Kecamatan seluruh Indonesia. Puncaknya pada Tahun 2013 diturunkanlah aturan Instruksi Direktur Jenderal Bimas Islam No. DJ.II/369 Tahun 2013 tentang Penerapan SIMKAH pada KUA Kecamatan.4

SIMKAH awalnya merupakan sebuah program aplikasi komputer berbasis desktop yang berguna untuk mengumpulkan data-data nikah dari seluruh KUA di Indonesia secara online. SIMKAH merupakan bentuk pemoderenan dalam pencatatan perkawinan. SIMKAH merupakan inovasi terbaru dalam mengoptimalkan kinerja KUA, membantu dalam pendaftaran nikah dan memudahkan pemberian informasi kepada masyarakat secara online, sehingga kemungkinan perkawinan yang tidak dicatatkan dapat diminimalisir. Penggunaan SIMKAH berbasis desktop dapat menyimpan database milik calon pengantin, sehingga tidak membutuhkan waktu yang lama ketika ingin menemukan dan membukanya kembali.

Dalam penerapannya, mulai bulan Oktober tahun 2018, SIMKAH telah mengalami perubahan dari yang awalnya berbasis desktop hingga sekarang berbasis web. Penerapan SIMKAH

haknya sebagai ahli waris. Lihat Abdul Manan, Aneka Masalab Hukum Perdata Islam di Indonesia, (Jakarta: Kencana, 2006), xx.

3 Peraturan Menteri Agama Republik Indonesia No. 19 Tahun 2018 tentang Pencatatan Perkawinan, https://bimasislam.kemenag.go.id/uploads/files/PMA\%252019.pdf.

4 Instruksi Dirjen Bimas Islam No. DJ.II-369 Tahun 2013, https://bimasislam.kemenag.go.id/pustaka/images/materibuku/instruksi.pdf. 
berbasis web didasarkan pada Peraturan Menteri Agama (PMA) RI Nomor. 20 Tahun 2019 tentang Pencatatan Perkawinan. SIMKAH berbasis web telah disosialisasikan di beberapa daerah termasuk Surabaya. Oleh sebab itu, diperlukan studi lapangan di KUA untuk mengetahui secara mendalam terkait perubahan SIMKAH tersebut dan sejauh mana kemaslahatan yang dapat dirasakan. Mengingat suatu perubahan yang terjadi, tentunya harus diiringi dengan adanya unsur kemaslahatan yang dapat dirasakan, baik oleh Pegawai KUA maupun masyarakat.5

Persoalan yang muncul kemudian, dalam implementasi SIMKAH berbasis web ditemukan beragam permasalahan. Seperti yang terjadi di KUA Gayungan Kota Surabaya, dimana meskipun sudah menerapkan SIMKAH berbasis web, namun SIMKAH berbasis Desktop juga masih digunakan. Kebijakan ini diambil karena SIMKAH berbasis web dinilai masih kurang efektif. Padahal sejak dikeluarkannya PMA Nomor. 20 Tahun 2019 tentang Pencatatan Pernikahan, maka KUA Kecamatan di Indonesia seharusnya sudah beralih sepenuhnya dari penggunaan SIMKAH berbasis desktop. Masalah lain ialah SIMKAH berbasis web belum sepenuhnya bisa dianggap sebagai jalan keluar atas permasalahan dalam pencatatan perkawinan. Karena kenyataan yang dirasakan oleh calon pengantin justru kian mempersulit.

Berdasarkan permasalahan di atas, artikel ini akan membedah tentang: bagaimana latar belakang perubahan dari SIMKAH berbasis desktop ke SIMKAH berbasis web? mengapa Kepala KUA Gayungan Kota Surabaya membuat kebijakan terkait implementasi SIMKAH Ganda? Dalam rangka menjawab pertanyaan-pertanyaan tersebut, penulis berupaya meninjau penerapan SIMKAH Ganda di KUA Gayungan berdasarkan teori efektivitas hukum dan apakah dapat digolongkan sebagai kebijakan strategis transformatif.

5 Aspek kemaslahatan menjadi penting sebab dalam penetapan sebuah hukum, Islam turut memperhatikan dinamika yang berkembang dalam masyarakat. Mengingat tujuan dari adanya suatu hukum dalam Islam ialah untuk melindungi kemaslahatan manusia, baik di dunia maupun di akhirat. Lihat Faiz Azkiya Arsyad, 'Dampak Peraturan Pemerintah Nomor 48 Tahun 2014 terhadap Masyarakat dan Penghulu (Studi di KUA Gondokusuman dan Tegalrejo Yogyakarta)', Jurnal AlAhwäl, Vol. 10, No. 2, Desember 2017, 199. 
Pada umumnya, kebijakan dijadikan sebagai panduan umum dalam mengimplementasikan suatu hal. Tidak dapat dipungkuri bila di kemudian hari terdapat perubahan strategi, sehingga diikuti pula dengan perubahan kebijakan. Dalam hal ini, kebijakan merupakan keputusan formal instansi yang mengatur perilaku dengan tujuan untuk menciptakan tata nilai baru, mencapai potensi yang tinggi, serta memperbaiki kehidupan sehari-hari, baik dalam tataran internal maupun eksternal.6 Adanya pemberian respon yang dapat memengaruhi unsur internal atau eksternal yang mencoba untuk mengarahkan kepada suatu perubahan disebut dengan transformasi.7

Penilaian terhadap efektivitas, tentunya tidak dapat dipisahkan dengan keberhasilan terhadap suatu tugas atau kebijakan yang telah direncanakan. 8 Keberhasilan atas kebijakan tersebut dapat diukur dengan tidak adanya tekanan atau ketegangan dalam penerapannya.9 Persoalan efektivitas hukum erat kaitannya dengan penerapan, pelaksanaan dan penegakan hukum dalam masyarakat agar terwujudnya tujuan dari suatu hukum. Mengingat dalam realitas sosial, seringkali implementasi hukum tidak berjalan efektif. Sehingga wacana tersebut menjadi menarik untuk dikupas dengan menggunakan perspektif efektivitas hukum.10

Penelitian lapangan ini menggunakan metode deskriptif kualitatif dan analisis datanya menggunakan fenomenologis. Pengambilan data dilakukan melalui wawancara dan observasi

6 William N. Dunn, Analisis Kebijakan, diterjemahkan oleh Samodra Wibawa, dkk, (Yogyakarta: UGM Press, 1999), 55.

7 Faktor-faktor yang dapat menyebabkan terjadinya transformasi, di antaranya: kebutuhan identitas diri, perubahan gaya hidup, perubahan struktur dan kondisi masyarakat, serta pengaruh teknologi. Lihat Ernita Dewi, 'Transformasi Sosial dan Nilai Agama', Jurnal Substantia, Vol. 14, No. 1, April 2012, 113-114.

8 Barda Nawawi Arief, Kapita Selekta Hukum Pidana, (Bandung: Citra Aditya Bakti, 2012), 85.

9 Agung Kurniawan, Transformasi Pelayananan Publik, (Yogyakarta: Pembaharuan, 2005),. 109.

10 Efektivitas hukum sangat berhubungan dengan usaha menanamkan hukum dalam masyarakat, yang acapkali menimbulkan reaksi yang berbeda sebab didasarkan pada sistem nilai-nilai yang berlaku. Lihat Soerjono Soekanto, Beberapa Aspek Sosial Yuridis Masyarakat, (Bandung: Alumni, 1995), 45. 
partisipatoris dalam rangkaian experiential learning.11 Kedudukan penelitian ini kian terasa dibutuhkan sebab penelitian-penelitian yang ada sebelumnya, hanya terkait dengan penerapan SIMKAH sebagai upaya pencegahan manipulasi data dalam pencatatan pernikahan.12 Pun demikian dapat dilihat bahwa kebanyakan penelitian baru membahas SIMKAH berbasis desktop. Mengingat SIMKAH berbasis web masih terbilang hal baru, karena baru resmi digunakan pada awal Tahun 2019. Sehingga masih minim literatur yang menjelaskan terkait implementasi SIMKAH berbasis web di KUA Kecamatan.13

\section{Deskripsi Efektivitas Hukum}

Efektivitas secara etimologi berasal dari kata efektif yang memiliki makna berhasil. Sedangkan menurut kamus besar bahasa Indonesia (KBBI) efektivitas adalah keefektifan, yaitu keberhasilan suatu usaha, tindakan.14 Sedangkan dalam bahasa Belanda effectief memiliki makna berhasil guna. Sehingga efektivitas hukum secara tata bahasa dapat diartikan sebagai manfaat hukum. Hal tersebut

11 Cara pengambilan data tersebut dipilih oleh penulis dengan beberapa pertimbangan, yakni: 1) Kebanyakan penelitian hukum masih menggunakan metode normatif-sosisologis. 2) Perbedaan paling mencolok dengan metode experiential learning, penulis kali ini dapat turut terlibat secara langsung untuk memahami masalah berdasarkan pengalaman yang dirasakan oleh Pegawai KUA dan Masyarakat. 3) Metode ini memiliki 4 tahapan yang menurut penulis dapat memecahkan rumusan masalah yang ada dalam penelitian ini, yaitu dimulai dari tahap pengalaman, kemudian tahap refleksi, tahap konseptualisasi, dan ditutup dengan tahap doing.

12 Misalnya penelitan yang dilakukan oleh Mohamad Abdul Faqih Mahbub, dengan judul Efektivitas Sistem Informasi Manajemen Nikah (SIMKAH) dalam Pencatatan Nikah di KUA Jombang. Kemudian penelitian yang dilakukan oleh Andi Imran Paturusi, dengan judul Pemeriksaan dan Pengawasan Perkawinan di Kantor Urusan Agama Kecamatan Klojen Kota Malang: Studi tentang Penggunaan Sistem Informasi Manajemen Nikah (SIMKAH).

13 Misalnya penelitan yang dilakukan oleh Tegar Setyo Pribadi, Taufik Baidawi dan Siti Marlina, dengan judul Sistem Informasi Administrasi Nikah Berbasis Web pada KUA Bantar Gebang Bekasi. Kemudian penelitan yang dilakukan oleh Nur Fadilah dan Titi Sriwahyuni, dengan judul Perancangan Aplikasi Layanan Administrasi Pernikahan Berbasis Web.

14 Kamus Besar Bahasa Indonesia, (Jakarta: Balai Pustaka, 2002), 284. 
berkenaan dengan keberhasilan pelaksanaan hukum, sejauh mana hukum atau peraturan berjalan optimal, efisien, dan tepat sasaran.

Pada dasarnya efektivitas merupakan tingkat keberhasilan dalam pencapaian tujuan. Efektivitas yaitu pengukuran dalam arti tercapainya sasaran atau tujuan yang telah ditentuka sebelumnya. Menurut Lawrence M. Friedman dalam bukunya yang berjudul " $L$ aw and Society", mengatakan bahwa efektif atau tidaknya suatu aturan atau perundang-undangan sagat dipengaruhi oleh tiga faktor, yang dikenal dengan efektivitas hukum. Tiga faktor tersebut yaitu substansi hukum, strukrtur hukum, dan budaya hukum.

Dalam sosiologi hukum, hukum memilii fungsi sebagai a tool of social control, yaitu upaya untuk mewujudkan kondisi seimbang di dalam masyarakat, yang bertujuan terciptanya suatu keadaan yang serasi antara stabilitas perubahan di dalam masyarakat. Selain itu hukum juga memiliki fungsi lain yaitu sebagai a tool of social engineering yang memiliki makna sebagai sasaran pembaharuan dalam masyarakat. Hukum dapat berperan dalam mengubah pola pemikiraan yang rasional atau modern. Efektivitas hukum merupakan proses yang tidak lain memiliki tujuan supaya hukum berjalan secara efektif. 15

Ketika ingin mengetahui sejauh mana efektivitas dari hukum, maka pertma-tama harus dapat mengukur sejauh mana hukum itu ditaati oleh sebagian besar target yang menjadi sasaran ketaatannya, barulah dapat dikatakan bahwa aturan hukum yang bersangkutan adalah efektif. Namun, sekalipun dikatakan aturan yang efektif, tetapi tetap dapat dipertanyakan lebih jauh derajat efektivitasnya karena seseorang menaati atau tidak suatu hukum tergantung pada kepentingannya.16

Soerjono Soekanto menggunakan tolak ukur efektivitas dalam penegakan hukum pada 5 hal yaitu faktor hukum, faktor penegakan hukum, faktor sarana atau fasilitas pendukung, faktor masyarakat,

15 Achmad Ali, Menguak Teori Hukum (Legal Theory) dan Teori Peradilan (Judicaialprudence) Termasuk Intepretasi Undang-Undang (Legisprudence), (Jakarta: Kencana, 2009), 375.

16 Ibid., 376. 
dan faktor kebudayaan.17 Kelima faktor terssebut saling berkaitan dengan eratnya, karena menjadi hal pokok dalam penegakan uku, serta sebagai tolak ukur dari efektivitas penegakan hukum. Dari lima faktor penegakan hukum tersebut, faktor penegakan hukumnya sendiri merupakan titik sentralnya. Hal ini disebabkan baik oleh undang-undangnya disusun oleh penegak hukum, penerapannya pun dilaksanakan oleh penegak hukum dan penegak hukumnya sendiri juga merupakan panutan oleh masyarakat luas. 18

\section{Deskripsi Kebijakan Strategis Transformatif}

Menurut Udoji pakar kebijakan asal Afrika, pelaksanaan kebijakan merupakan hal yang sangat penting dan mungkin jauh lebih penting daripada pembuatan kebijkan. Namun baru pada akhir dasawarsa ini, para ilmuwan sosial, menaruh perhatian yang besar terhadap proses perumusan kebijakan (public policy formulation). Pada umumnya, penelitian pada waktu yang lalu oleh para ahli, lebih cenderung untuk memperthatikan pada masalah keputusan (decision) daripada masalah kebijakan. Sehingga, para ahli lebih memperhatian masalah the moment of choice. Fokus para ahli yaitu saat-saat ditentukannya pemilihan alternatif atau saat-saat di mana layaknya suatu keputusan diambil, atau suatu strategi kebijakan tertentu dibuat atau dirumuskan.19

Pembuat kebijakan publik adalah para pejabat-pejabat publik, termasuk para pegawai senior pemerintah yang memiliki tugas untuk memikirkan dan memberikan pelayanan demi kebaikan publik atau kemaslahatan umum (public good). Fisterbusch (1983) membagi kebijakan publik dalam lima unsur, yaitu keamanan (security), hukum dan ketertiban umum (law and order), keadilan (justice), kebebasan (liberty), dan kesejahteraan (welfare).20

17 Soerjono Soekanto, Faktor-Faktor yang Mempengarubi Penegakan Hukum. (Jakarta: PT Raja Grafindo Persada., 2007), 5.

18 Ibid., 8.

19 Solicin Abdul Wahab, Analisis Kebijakan: Dari Formulasi ke Penyusunan ModelModel Implementasi Kebijakan Publik. (Jakarta: PT Bumi Aksara). 126

20 Ibid., 111. 
Kebijakan publik apapun sebenarnya mengandung resiko untuk gagal. Hogwood dan Gunn (1986) telah membagi pengertian kegagalan kebijakan (policy failuare) dalam dua kategori besar, yaitu:21 1. Non-implementation (tidak terimplementasi)

2. Usuccessfull implementation (implementasi yang tidak berhasil)

Tidak terimplementasikan memiliki makna bahwa suatu kebijakan tidak dilaksanakan sesuai dengan rencana, mungkin karena pihak-pihak yang terlibat di dalam pelaksanannya tidak mau berkerjasama, atau mereka telah bekerja secara tidak efisien, bekerja setengah hati, atau Karena tidak menguasai permasalahan. Sehingga, betapapun gigih usaha mereka, hambatan-hambatan yang ada tidak sanggup teratasi.

Sedangkan, implementasi yang tidak berhasil biasanya terjadi ketika suatu kebijakan tertentu telah dilaksanakan sesuai rencana, namun ada kondisi yang tidak menguntungkan. Biasanya, kebijakan yang memiliki resiko untuk gagal disebabkan oleh beberapa faktor berikut, yaitu pelaksanannya jelek (bad execution), kebijakannya sendiri memang jelek (bad policy), dan kebijakan yang bernasib jelek (bad luck).

Dengan demikian, suatu kebijakan boleh jadi tidak dapat diimplementasikan secara efektif sehingga dinilai oleh para pembuat kebijakan sebagai pelaksanaan yang jelek. Atau baik pembuat kebijakan (policymakers) maupun mereka yang ditugasi untuk melaksanakannya (implementing agencies or implementing actors) samasama sepakat bahwa kondisi eksternal benar-benar tidak menguntungkan bagi efektifitas implementasi, sehingga tidak seorang pun perlu dipersalahkan.

Tidak dapat dipungkuri bila di kemudian hari terdapat perubahan strategi, sehingga diikuti pula dengan perubahan kebijakan. Dalam hal ini, kebijakan merupakan keputusan formal instansi yang mengatur perilaku dengan tujuan untuk menciptakan tata nilai baru, mencapai potensi yang tinggi, serta memperbaiki kehidupan sehari-hari, baik dalam tataran internal maupun eksternal.22 Adanya pemberian respon yang dapat memengaruhi

21 Ibid., 128

22 Wibawa, dkk, Analisis Kebijakan (Yogyakarta: UGM Press, 1999), 55. 
unsur internal atau eksternal yang mencoba untuk mengarahkan kepada suatu perubahan disebut dengan transformasi.23

\section{Substansi SIMKAH Berbasis Desktop dan Web}

SIMKAH berbasis desktop merupakan sebuah aplikasi komputer yang berguna untuk mengumpulkan data-data nikah, dimana data tersebut dapat dibuat sebagai analisa dan laporan sesuai dengan beragam kebutuhan. Penyeragaman data di KUA sangat diperlukan agar lebih efektif dan efesien dalam penanganannya melalui suatu program yang memadai. SIMKAH lahir setelah Bimas Islam berpisah dengan Ditjen Penyelenggaraan Haji dan Umrah. Tekad ini demi mewujudkan pelayanan administrasi berbasis teknologi. Keefektifan dalam penggunaan SIMKAH merupakan salah satu unsur penilaian dalam pemilihan KUA teladan Nasional.24

Urgensitas SIMKAH mulai terlihat sejak arus perkembangan teknologi informasi kian masif dan merajalela25, ditambah lagi dengan jumlah KUA yang berkisar sekitar 5.382 tentunya sangat membutuhkan peningkatan dalam pelayanan publik layaknya instansi pemerintahan yang lain.26 Prosedur pencatatan perkawinan di KUA sebelum lahirnya SIMKAH diatur dalam PP No. 9 Tahun 1975 tentang Pelaksanaan UU No. 1 Tahun 1974 tentang Perkawinan. Kemudian lahirlah SIMKAH dengan dasar hukum

23 Ernita Dewi, 'Transformasi Sosial dan Nilai Agama', Jurnal Substantia, Vol. 14, No. 1, April 2012, 113-114.

24 Dirjen Bimas Islam, Buku Panduan SIMKAH, dalam https://simbi.kemenag.go.id/pustaka/index.php/urusan-agamaislam/kepenghuluan/622-buku-panduan-sistem-informasi-manajemen-nikah. 25 Keberadaan sistem informasi di zaman serba teknologi ini kian terasa dibutuhkan oleh perusahaan, organisasi, lembaga maupun instansi lainnya. Tujuannya untuk menyampaikan informasi secara cepat dan sebagai usaha dalam peningkatan kualitas yang disertai dengan peningkatan kemampuan sumber daya. Lihat Dumaria Manurung, Dedi Suhendro dan Lisa Andrianti Opusunggu, 'Perancangan Sistem Informasi Pencatatan Biaya Operasional pada KUA Kecamatan Tanah Jawa', Jurnal TECHSI, Vol. 11, No. 2, Juli 2019, 219.

26 Thobib Al-Asyar, SIMKAH Cara Baru Pelayanan Administrasi Nikah di Era Digital, dalam https://simbi.kemenag.go.id/pustaka/images/materibuku/makalah-islamSIMKAH-cara-baru-pelayanan-administrasi-nikah-di-era-digital.pdf. Diakses pada tanggal 2 Oktober 2019. 
PMA No. 11 Tahun 2007 Jo. PMA No. 19 Tahun 2018 tentang Pencatatan Perkawinan dan Instruksi Direktur Jenderal Bimas Islam No. DJ.II/369 Tahun 2013 tentang Penerapan SIMKAH pada KUA Kecamatan.

Pada mulanya, tata cara pencatatan nikah di KUA menggunakan tinta hitam dan ditulis dengan huruf balok. Namun setelah adanya SIMKAH berbasis desktop, pencatatan nikah ditulis dan diketik oleh penghulu atau operator SIMKAH. Hal ini menjadikan pekerjaan KUA lebih efektif dan efisien. Tujuan utama penerapan SIMKAH di KUA ialah sebagai sistem penyeragaman data dan backup data yang terintegrasi, sehingga tidak mengandalkan bukti fisik saja. Program SIMKAH ini dirancang agar dapat diterapkan dengan mudah untuk semua golongan.27

Sebelum adanya SIMKAH, proses entry data calon pengantin kian terlihat longgar untuk dapat dimanipulasi, mengingat tidak adanya ketentuan khusus seperti harus mengikuti data dalam ijazah pendidikan terakhir. Calon pengantin diberi kebebasan untuk memilih data mana yang akan digunakannya dalam pendaftaran pernikahannya. Namun sejak dikeluarkannya UU No. 24 Tahun 2013 tentang Perubahan atas UU No. 23 Tahun 2006 tentang Administrasi Kependudukan, data yang digunakan dalam akta nikah harus berdasarkan pada Kartu Tanda Penduduk (KTP). Hal ini dikarenakan dalam KTP terdapat Nomor Induk Kependudukan (NIK) yang merupakan data induk yang telah terdaftar sebagai penduduk warga Negara.28

Dahulu SIMKAH masih berdiri sendiri. Namun saat ini, SIMKAH sudah terintegrasi dengan Catatan Sipil dalam hal penggunaan NIK yang ada dalam KTP. Sehingga sudah dapat melakukan validasi NIK pada saat entry data calon pengantin. Ditambah lagi, saat ini Kementerian Agama (Kemenag) telah melakukan Memorandum of Understanding (MoU) dengan Kementerian Dalam Negeri (Kemendagri). Sehingga dalam pengurusan data nikah dapat ditempuh dengan waktu yang singkat dan sederhana.

27 Dirjen Bimas Islam, Buku Panduan SIMKAH.

28 Undang-Undang No. 24 Tahun 2013 tentang Perubahan atas UU No. 23 Tahun 2006 tentang Administrasi Kependudukan, https://pih.kemlu.go.id/files/19.\%2520\%2520UU_\%2520NO\%252024. 
Setelah adanya SIMKAH berbasis desktop, Kemenag terus berkomitmen untuk selalu meningkatkan sistem pelayanan berbasis teknologi. Sehingga pada tanggal 30 September 2018, melalui Peraturan Menteri Agama (PMA) Republik Indonesia Nomor. 20 Tahun 2019 tentang Pencatatan Perkawinan, Kemenag meluncurkan SIMKAH berbasis web agar mulai diterapkan di seluruh KUA Kecamatan Indonesia. SIMKAH berbasis web ini banyak mendapatkan respons dan menjadi sorotan, baik dari operator SIMKAH di KUA sendiri maupun oleh masyarakat umum. Banyaknya respon tentu sangat dibutuhkan sebagai bahan evaluasi kebijakan pengembangan SIMKAH berbasis web.

SIMKAH berbasis desktop dilengkapi dengan berbagai fitur, yaitu:

1. Data Master, meliputi tempat KUA, Petugas (Penghulu dan P4), ID dan password.

2. Rekap Data, berupa jumlah bilangan terkait peristiwa pernikahan dalam sebulan atau setahun di KUA seluruh Indonesia dari berbagai sudut pandang.

3. Grafik, berupa gambaran grafik sebulan atau setahun terkait peristiwa pernikahan di KUA seluruh Indonesia.

4. Detail Komponen mulai pada saat pendaftaran nikah, pemeriksaan nikah dan pencatatan nikah.

5. Entry Data, meliputi pengisian berkas-berkas peristiwa pernikahan baik dari Model N1 sampai dengan N7, Model NB atau Akta Cerai.

Perkembangan teknologi yang kian mutakhir saat ini, menjadikan SIMKAH berbasis web sebagai suatu kebutuhan yang harus dipenuhi. Seperti sebelum diluncurkannya SIMKAH berbasis web, ditemukan beberapa penelitian terkait perancangan sistem informasi yang mengarah kepada basis web. Pertama, ditemukan penelitian tahun 2015 tentang Sistem Informasi Administrasi Nikah berbasis web pada KUA Bantar Gebang Bekasi. Desain website yang ditawarkan dengan menggunakan program seperti Dreamweaver, MySql dan beberapa plugin seperti Jquery. Tujuan dibuatnya sistem tersebut agar masyarakat dimudahkan dalam hal administrasi 
kehendak menikah melalui sistem online dan mengakses informasi secara realtime. 29

Kedua, pada tahun 2019 ditemukan penelitian tentang Aplikasi Layanan Administrasi Pernikahan berbasis Web. Aplikasi tersebut dibuat menggunakan bahasa pemrograman PHP: Hypertext Prepocessor dan menggunakan Framework Yii Advanced 2. Pembuatan aplikasi dilakukan setelah mendapati beragam permasalahan yang terjadi di KUA Kecamatan Pariaman Selatan dalam pengurusan administrasi pernikahan, seperti ketidaktahuan calon pengantin terhadap tahapan-tahapan administrasinya, mengurangi stigma negatif tentang sulitnya mengurus administrasi pernikahan dan mengurangi potensi calo dalam pengurusan administrasi nikah di KUA.30

Dengan adanya SIMKAH berbasis web, diharapkan dapat meningkatkan pelayanan pernikahan, mempermudah pemerintah dalam memantau peristiwa pernikahan, serta meminimalisir manipulasi data diri. Faktor lahirnya SIMKAH berbasis web diantaranya agar data dapat diakses oleh semua orang dan meningkatkan sistem integrasi pada internal KUA dan Kementerian lainnya. Perbedaan antara SIMKAH berbasis web dengan SIMKAH berbasis desktop adalah sebagai berikut31:

1. SIMKAH berbasis desktop dilengkapi dengan database, sedang di SIMKAH berbasis web belum ada. Sehingga KUA yang telah beralih ke SIMKAH berbasis web tidak memiliki dan tidak dapat melihat data yang sudah di-entry.

2. Dalam SIMKAH berbasis Web sudah disediakan barcode bagi pencatatan pernikahannya, sedang di SIMKAH berbasis desktop tidak ada. Saat barcode di-scan, maka akan muncul data-data terkait pencatatan perkawinan milik kedua pengantin. Hal ini

29 Tegar Setyo Pribadi, Taufik Baidawi dan Siti Marlina, 'Sistem Informasi Administrasi Nikah Berbasis Web pada KUA Bantar Gebang Bekasi', Prosiding SIMNASIPTEK, 2015, 110.

30 Nur Fadilah dan Titi Sriwahyuni, 'Perancangan Aplikasi Layanan Administrasi Pernikahan Berbasis Web’, Jurnal Voteknika, Vol. 7, No. 1, Maret 2019, 62.

31 Perbedaan ini penulis dapatkan setelah melakukan praktik secara pengalaman dalam mengaplikasikan SIMKAH berbasis Web dan Desktop di KUA Gayungan Kota Surabaya. 
memudahkan saat ingin melakukan legalisasi pernikahan atau membuktikan pernikahan yang telah dilakukan oleh pasangan suami istri.

3. Dengan adanya SIMKAH berbasis web dilengkapi dengan pencetakan kartu nikah. Kartu nikah tersebut dikeluarkan untuk memudahkan saat pasangan suami istri ingin membawa bukti nikah dalam perjalanan sehari-harinya. Hanya saja, aturan yang ada memperbolehkan kartu nikah untuk dicetak satu kali saja seumur hidup. Setiap pasangan suami istri hanya dapat memiliki satu kartu nikah saja. Kartu nikah hanya sebatas tambahan setelah adanya penerbitan buku nikah.

4. Pencatatan perkawinan di SIMKAH berbasis web dilakukan secara real-time, sedang di SIMKAH berbasis desktop tidak demikian. Real-time yang dimaksud ialah data nikah tidak bisa dientry bila pernikahanannya sudah berlalu. Selain itu, dalam entry data nikah harus dilakukan secara berurutan dan harus sudah selesai sehari sebelum pelaksanaan pernikahan.

5. Data terkirim otomatis melalui SIMKAH berbasis web. Tidak demikian dengan SIMKAH berbasis desktop, karena data dikirim ke Kemenag Pusat secara manual.

\section{Implementasi SIMKAH Ganda di KUA Gayungan Kota Surabaya}

Kantor Urusan Agama (KUA) merupakan satuan kerja di lingkungan Kementerian Agama (Kemenag) di Kecamatan, yang mana turut berperan dalam melaksanakan sebagian dari tugas Kantor Kemenag Kabupaten/Kota di bidang Urusan Agama Islam. Oleh sebab itu, tugas dan fungsi KUA tidak dapat dilepaskan dari tugas dan fungsi Kemenag. Bahkan KUA dianggap sebagai garda terdepan yang langsung bersentuhan dengan beragam hajat masyarakat. Sehingga dalam menjalankan tugas dan fungsinya, KUA dihadapkan oleh setumpuk masalah, seperti persoalan administrasi, kekurangan sumber daya manusia, tata kelola sistem dan kebijakan, sarana yang kurang mendukung, area kerja yang luas dengan tingkat kesulitan pada medannya, dan persoalan-persoalan lainnya.32

32 Syamsurijal, 'Dialektika Regulasi dan Tradisi dalam Pelayanan Perkawinan di KUA', Jurnal SMaRT, Vol. 03, No. 02, Desember 2017, 126. 
Tugas dan fungsi KUA yang telah ditetapkan oleh Peraturan Menteri Agama (PMA) No. 34 Tahun 2016 disebutkan dalam Pasal 3, di antaranya yakni: a) pelaksanaan pelayanan, pengawasan, pencatatan dan pelaporan nikah dan rujuk, b) penyusunan statistik layanan dan bimbingan masyarakat Islam, c) pengelolaan dokumentasi dan sistem informasi manajemen KUA Kecamatan, d) pelaksanaan ketatausahaan dan kerumahtanggaan KUA Kecamatan.33

Tiap-tiap Kecamatan di seluruh Indonesia memiliki KUA. KUA Kecamatan Gayungan merupakan salah satu KUA di Kota Surabaya, yang masuk ke dalam wilayah Surabaya Selatan. KUA Gayungan memiliki wilayah yurisdiksi yang cukup luas dengan membawahi 4 kelurahan, yakni Kelurahan Gayungan, Kelurahan Ketintang, Kelurahan Menanggal dan Kelurahan Dukuh Menanggal. Mulai Tahun 2018, KUA Gayungan dipimpin oleh M. Hasan Baisuni dengan dibantu oleh lima orang pegawai. Salah satu pegawai di KUA Gayungan bertugas sebagai operator SIMKAH, yang dalam hal ini dilaksanakan oleh Ahmad Zainul Ma'arif.

Seiring berjalannya waktu, Kota Surabaya menjadi berkembang dan penduduknya menjadi kian bertambah. Kecamatan Gayungan Kota Surabaya merupakan daerah yang penduduknya sangat agamis, plural dan primordial. Berdasarkan data terakhir yang diperoleh penulis, penduduk Kecamatan Gayungan berjumlah 47.635 jiwa, dengan perincian 40.802 jiwa beragama Islam, 4.070 jiwa beragama Kristen, 2.191 jiwa beragama Katholik, 367 jiwa beragama Hindu dan 203 jiwa beragama Buddha.34

Sejak diresmikannya SIMKAH berbasis web35, maka seluruh KUA Kecamatan di Indonesia harus sudah beralih dari SIMKAH

33 Peraturan Menteri Agama Republik Indonesia No. 34 Tahun 2016 tentang Organisasi dan Tata Kerja Kantor Urusan Agama Kecamatan, https://bimasislam.kemenag.go.id/uploads/files/PMA-34-update.pdf.

34 Laporan Data Kependudukan KUA Gayungan Tahun 2019.

35 Di Surabaya sendiri terkait sosialisasi SIMKAH berbasis Web sudah dilakukan dua kali, yakni pada bulan Oktober tahun 2018 oleh Kanwil Surabaya dan bulan Desember tahun 2018 oleh Kemenag Surabaya. Adapun SIMKAH berbasis Web sudah resmi digunakan oleh KUA di Surabaya sejak bulan Februari tahun 2019. Ahmad Zainul Ma'arif, Wawancara, (Gayungan, 1 Oktober 2019). 
berbasis desktop. Pun demikian dengan KUA Gayungan Kota Surabaya. Namun, beberapa bulan setelah beralih ke SIMKAH berbasis web, operator SIMKAH36 di KUA Gayungan merasa sangat perlu untuk kembali menggunakan SIMKAH berbasis desktop. Hal inilah yang kemudian menjadikan Kepala KUA Gayungan mengeluarkan kebijakan untuk menerapkan SIMKAH Ganda, yakni SIMKAH berbasis web dan desktop.

Alasan dikeluarkannya kebijakan implementasi SIMKAH Ganda oleh Kepala KUA Gayungan ialah karena mulanya memahami bahwa adanya SIMKAH berbasis web seharusnya dapat melengkapi SIMKAH berbasis desktop. Namun, kenyataan yang terlihat selanjutnya justru tidak serta merta seperti itu, banyak problematika yang ditimbulkan bila sepenuhnya beralih dari SIMKAH berbasis desktop menuju SIMKAH berbasis web.37 Di antaranya ialah data nikah yang sudah di-entry tetap dibutuhkan di kemudian hari, sehingga penggunaan SIMKAH berbasis desktop sangatlah diperlukan. Mengingat data nikah yang sudah di-entry pada SIMKAH berbasis web belum bisa untuk dilihat kembali dan tidak ada inventarisasi datanya. Selain itu, adanya SIMKAH berbasis desktop dapat mempermudah operator SIMKAH dalam membuat laporan bulanan atau tahunan kepada Kemenag, karena banyaknya komponen yang belum terakomodir dalam SIMKAH berbasis web.38

SIMKAH berbasis web memang masih tergolong hal baru, sehingga dalam penerapannya masih sering perbaikan server dan trouble. Untuk mengantasipasi hal tersebut, maka KUA Gayungan membuat kebijakan agar tetap menerapkan SIMKAH berbasis desktop.39 Sehingga pada saat server diperbaiki atau sedang

36 Dalam menjalankan SIMKAH, beberapa KUA di Surabaya lebih melihat pada keadaan Sumber Daya Manusia (SDM) penghulunya. Bila merasa mampu, maka SIMKAH dioperasionalkan secara langsung oleh penghulu. Namun bila SDM penghulunya kurang, maka SIMKAH dijalankan oleh operator yang sudah ditunjuk oleh Kepala KUA. Dalam hal ini, di KUA Gayungan Kota Surabaya memiliki operator SIMKAH secara khusus. Ahmad Zainul Ma'arif, Wawancara, Gayungan, 1 Oktober 2019.

37 M. Hasan Baisuni, Wawancara, Gayungan, 14 Oktober 2019. 38 Ahmad Zainul Ma'arif, Wawancara, Gayungan, 8 Oktober 2019. 39 M. Hasan Baisuni, Wawancara, Gayungan, 14 Oktober 2019. 
mengalami trouble, kegiatan pencatatan nikah masih tetap dapat dijalankan, meskipun pada praktiknya menjadikan operator SIMKAH untuk berkerja dua kali. Namun persoalan kerja dua kali bukanlah suatu masalah bagi operator SIMKAH di KUA Gayungan.40

Terkait penghapusan data nikah yang sudah di-entry pada SIMKAH berbasis web terbilang sangat lambat, sehingga operator SIMKAH harus menunggu terlebih dahulu sampai data yang dihapusnya benar-benar sudah tidak muncul di SIMKAH berbasis web. Setelah data sudah benar-benar terhapus, maka operator SIMKAH harus memulai lagi entry data dari awal. Hal inilah yang kemudian juga menjadi alasan mengapa diperlukan penerapan SIMKAH Ganda di KUA Gayungan. Tujuannya, agar data nikah masih dapat tersimpan, sehingga pada saat SIMKAH berbasis web belum menghapus data nikah yang sudah di-entry, operator SIMKAH sudah memiliki back-up datanya.41

Adanya SIMKAH berbasis web memang sudah menjadi kebutuhan di era teknologi yang kian berkembang pesat. Perubahan dari SIMKAH berbasis desktop menuju SIMKAH berbasis web merupakan suatu langkah dalam mempersempit ruang gerak buku nikah palsu dan meminimalisir kesalahan saat entry data nikah. Pada saat entry data nikah calon mempelai laki-laki, calon mempelai perempuan, wali nikah dan saksi-saksi, baik SIMKAH berbasis web maupun SIMKAH berbasis desktop sudah menggunakan data yang ada dalam Nomor Induk Kependudukan (NIK). Sehingga operator SIMKAH cukup memasukkan NIK, maka data pribadi yang bersangkutan dapat langsung terisi secara otomatis.

Implikasi atas penggunaan NIK dalam SIMKAH yaitu terkadang data yang keluar secara otomatis tidak sesuai dengan data yang sebenarnya, karena pihak yang bersangkutan belum memperbarui datanya di Kantor Catatan Sipil. Dalam mengatasi data yang tidak sesuai, maka operator SIMKAH KUA Gayungan menyarankan pihak yang bersangkutan untuk mengurus perubahan datanya di Kantor Catatan Sipil bila waktu pelaksanaan akad

40 Ahmad Zainul Ma'arif, Wawancara, Gayungan, 8 Oktober 2019.

41 Ibid. 
nikahnya masih terhitung jauh. Bila tidak memungkinkan, maka pihak yang bersangkutan membuat Surat Pernyataan Kesalahan Data bermaterai yang berisikan perubahan datanya.42

Dalam tata laksana pencatatan pernikahan, dimulai dari pemberitahuan kehendak nikah, yang dilaksanakan secara tertulis dengan mengisi formulir pemberitahuan dan dilengkapi dengan persyaratan berkas-berkasnya. Setelah data terkumpul, operator SIMKAH melakukan entry data tersebut ke SIMKAH. Kemudian diadakan proses pemeriksaan calon mempelai dan wali nikah, atau biasa dikenal dengan sebutan rafa'. Bila proses rafa' telah dilalui, maka operator SIMKAH melakukan print akta nikah, serta print buku nikah. Dengan menggunakan data nikah yang ada dalam SIMKAH berbasis desktop, maka print out yang dihasilkan lebih rapi daripada hasil print out dari template yang ada pada SIMKAH berbasis web, sebab template yang disediakan sering tidak sesuai (melenceng dari garis-garis yang ada) dan font yang dipakai terlalu besar.43

Masih minimnya sosialisasi dalam pengimplementasian SIMKAH berbasis web menjadikan operator SIMKAH masih kesulitan menjalankannya. Ditambah lagi dengan Sumber Daya Manusianya yang juga terbilang kurang, karena harus ada pegawai yang merangkap tugasnya demi tetap mengoperasikan SIMKAH berbasis Web.44

\section{Tinjauan Kebijakan Strategis Transformatif dan Efektivitas Hukum}

KUA Kecamatan dituntut untuk selalu tampil prima dalam melayani masyarakat demi terwujudnya ketertiban dan kepastian hukum.45 Guna melaksanakan tugasnya, kegiatan-kegiatan yang berkaitan dengan masalah perkawinan, perceraian dan rujuk harus

42 Ibid.

43 M. Hasan Baisuni, Wawancara, Gayungan, 14 Oktober 2019.

44 Dengan menggunakan pendekatan experiential learning, penulis dapat merasakan secara pengalaman bahwa faktor-faktor yang menjadi alasan dikeluarkannya kebijakan implementasi SIMKAH Ganda di KUA Gayungan memang menciptakan berbagai permasalahan. Permasalahan yang cukup kompleks tersebut, belum ada jalan keluar yang diberikan oleh Kemenag Pusat.

45 Hal ini sebagaimana ditegaskan dalam Pasal 2 ayat 2 UUP dan Pasal 5 ayat 1 KHI. 
disertai dengan bukti yang lengkap dan diproses melalui pencatatan secara tertib dan masif.

Kegiatan administrasi dalam pencatatan nikah di KUA Gayungan telah terfasilitasi dengan sangat baik, yakni dengan menerapkan SIMKAH. Sesuai dengan fungsinya, SIMKAH sangat membantu para penghulu dalam menjalankan tugasnya dan datadata pernikahan dapat diamankan. Sejatinya SIMKAH berlaku khusus, karena SIMKAH hanya dapat diakses oleh pihak KUA dan server pusat saja.

Secara umum, KUA Kecamatan telah beralih dari SIMKAH berbasis desktop menuju SIMKAH berbasis web. Namun tidak demikian dengan KUA Gayungan Kota Surabaya. Kebijakan baru dibuat oleh Kepala KUA Gayungan, yakni dalam pencatatan perkawinan bagi masyarakatnya ialah dengan menerapkan SIMKAH ganda. Dengan begitu, berarti selain diterapkannya SIMKAH berbasis web, SIMKAH berbasis desktop juga tidak ditinggalkan layaknya KUA Kecamatan lainnya.

Kebijakan terkait implementasi SIMKAH ganda di KUA Gayungan sangat menarik diteliti, mengingat kebijakan tersebut merupakan perubahan strategi yang dilakukan oleh Kepala KUA Gayungan setelah banyaknya permasalahan yang muncul saat SIMKAH berbasis web diterapkan. Sehingga diperlukan suatu gambaran secara komprehensif apakah kebijakan tersebut dapat digolongkan sebagai kebijakan yang strategis transformatif.

Berdasarkan pengamatan penulis di lapangan, ditemukan beberapa alasan kuat bahwa adanya kebijakan penerapan SIMKAH ganda di KUA Gayungan merupakan suatu kebijakan strategis transformatif. Pertama, karena dalam SIMKAH berbasis Web tidak dilengkapi dengan database. Padahal database sangat diperlukan, baik bagi pihak internal KUA maupun eksternal yakni para pengantin yang telah mencatatkan perkawinannya. Oleh sebab itu, kebijakan diterapkannya SIMKAH ganda merupakan langkah strategis transformatif agar database masih dimiliki dan dapat dicari untuk keperluan-keperluan di kemudian hari.46

46 Mengingat bila database tidak dimiliki oleh SIMKAH, maka proses pengambilan data menjadi lebih sulit dan lambat, serta keamanan datanya menjadi kurang terjamin. LIhat Ade Putra Nanda, 'Analisa dan Perancangan Sistem 
Kedua, data nikah yang di-entry pada SIMKAH berbasis web dilakukan secara real-time, sehingga bila pernikahan sudah dilakukan, maka tidak dapat lagi untuk dicatatkan. Padahal fakta di lapangan, SIMKAH berbasis web sering mengalami trouble dan perbaikan server. Dengan begitu, adanya kebijakan dalam implementasi SIMKAH ganda dapat digolongkan sebagai kebijakan strategis transformatif, karena pada saat SIMKAH berbasis web sedang trouble atau perbaikan server, kegiatan pencatatan perkawinan dapat tetap dilangsungkan.

Ketiga, KUA dituntut memberikan laporan secara bulanan dan tahunan. Sehingga adanya kebijakan SIMKAH ganda dapat dirasakan kemudahannya oleh operator SIMKAH yang bertugas membuat laporan-laporan tersebut. Mengingat dalam SIMKAH berbasis desktop, data terkait peristiwa-peristiwa nikah yang terjadi di KUA selama sebulan dan setahun dapat mudah dilihat dan dikelola menjadi laporan KUA.

Keempat, SIMKAH berbasis web terbilang sangat lambat dalam menghapus data nikah yang telah di-entry. Tak ayal, operator SIMKAH harus menunggu terlebih dahulu sampai data yang dihapus dapat dipastikan tidak muncul di layar SIMKAH. Penghapusan data nikah pada praktiknya pernah sampai berharihari, sehingga kebijakan diterapkannya kembali SIMKAH berbasis desktop merupakan langkah strategis, agar saat data akan di-entry kembali, back-up data telah dimiliki oleh operator. Mengingat saat data telah terhapus, operator harus mengulang dari awal untuk kembali entry data nikah di SIMKAH berbasis Web.

Kelima, pada praktiknya, hasil print out akta nikah dan buku nikah telah dilihat secara langsung oleh penulis. Tidak dapat dipungkiri bahwa hasil print out tersebut dapat dinilai sangat kurang rapi, karena melenceng dari garis-garis dan font yang dipakai terlalu besar. Sehingga kebijakan strategis transformatif berupa penerapan SIMKAH Ganda harus dilakukan, agar hasil print out dapat rapi dan tidak dipermasalahkan oleh para pengantin.

Suatu kebijakan yang telah dibuat tentunya juga harus berjalan beriringan dengan keefektifannya. Terlebih lagi dengan kebijakan

Informasi Pengolahan Data Pernikahan pada Kantor Urusan Agama (KUA)', Jurnal J-CLICK, Vol. 5, No. 1, Juli 2018, 91. 
terkait penerapan dan pelaksanaan hukum di masyarakat. Kebijakan hukum yang telah diterapkan harus jelas bermanfaat bila dilihat dari kacamata efektivitas hukum. Mengingat fakta yang terjadi di lapangan, seringkali ditemukan bahwa implementasi hukum tidak dijalankan secara efektif. Sehingga banyak kebijakan-kebijakan baru yang disinyalir mampu menuntaskan permasalahan yang dirasakan oleh masyarakat.

Pun demikian dengan kebijakan yang diambil oleh Kepala KUA Gayungan tentang implementasi SIMKAH ganda, tentunya juga harus dilihat sejauh mana keefektifannya. Sehingga secara hukum apakah dapat dinilai sebagai kebijakan yang efektif untuk diterapkan, bahkan diikuti oleh KUA-KUA lainnya di seluruh Indonesia. Dalam menguji alasan-alasan kebijakan tersebut dibuat, penjelasan secara rinci akan ditampilkan oleh penulis.

Pertama, terkait dengan database. Adanya database dari data-data nikah sangatlah diperlukan. Keperluan tersebut sebagaimana dikatakan oleh Ahmad Zainul Ma'arif selaku operator SIMKAH di KUA Gayungan. Zainul membutuhkan database guna mempermudah bila di kemudian hari para pengantin memerlukan data-datanya.47 Tak berbeda dengan MF, sebagai pengantin yang mendaftarkan perkawinannya di KUA Gayungan, juga turut memberikan pendapatnya terkait penerapan SIMKAH ganda. Kemanfaatan adanya kebijakan tersebut dirasakan oleh MF setelah perkawinannya dilangsungkan, yakni saat ia memerlukan kembali data-data nikah yang sudah didaftarkannya.48

Kedua, data nikah yang harus di-entry secara real-time memang dapat membuat tertib administratif. Namun kenyataan di lapangan justru menuai beragam permasalahan, seperti yang dirasakan oleh LZ. Sebagai calon pengantin perempuan, LZ sangat mendukung adanya kebijakan tentang implementasi SIMKAH ganda di KUA Gayungan. Dukungan tersebut kemudian menuai sedikit kekecewaan disebabkan saat data nikah yang hendak di-entry ke SIMKAH berbasis Web mengalami kegagalan sebab adanya perbaikan server dari pusat. Padahal tanggal pernikahannya sudah

47 Ahmad Zainul Ma'arif, Wawancara, Gayungan, 22 Oktober 2019. 48 MF, Wawancara, Gayungan, 22 Oktober 2019. 
sangat dekat. Oleh sebab itu, data nikah LZ akhirnya di-entry ke SIMKAH berbasis desktop agar buku nikahnya dapat dicetak.49

Dengan demikian, dapatlah dipahami bahwa penerapan SIMKAH ganda merupakan solusi yang strategis saat server mengalami perbaikan. Mengingat bila tanggal pernikahannya sudah terlewati, maka data nikah sudah tidak dapat di-entry kembali ke SIMKAH berbasis web. Tidak adanya pengumuman dari Kemenag Pusat bila SIMKAH berbasis web akan diperbaiki membuat permasalahan yang ditimbulkan kian rumit, karena pihak KUA sendiri tidak mungkin untuk terus menebak-nebak kapan akan selesai diperbaiki. Padahal data nikah yang telah disetorkan tidak dapat berlarut-larut dibiarkan begitu saja. Oleh sebab itulah, LZ juga menyayangkan karena adanya perbaikan server membuat kartu nikah yang menjadi haknya tidak dapat dimiliki selamanya.50

Ketiga, laporan bulanan dan tahunan sudah menjadi kewajiban tiap KUA Kecamatan di Indonesia. Oleh sebab itu, kebijakan SIMKAH Ganda dianggap mampu mempermudah Zainul untuk membuat laporan-laporan KUA Gayungan. Mengingat pada SIMKAH berbasis desktop dapat mengambil data-data yang diperlukan dan dapat langsung dibuat ke dalam excel. Kelebihan tersebut belum terakomodir dalam SIMKAH berbasis web.51

Keempat, terkait penghapusan data yang sangat lambat di SIMKAH berbasis web diakui oleh MFA. Masalah tersebut dapat diatasi oleh operator SIMKAH dengan turut meng-entry data nikah

49 LZ, Wawancara, Gayungan, 15 Oktober 2019.

50 Kartu nikah harus dicetak sebelum akad nikah dilangsungkan. Pencetakan kartu nikah hanya bisa melalui SIMKAH berbasis Web. Oleh karena saat itu server sedang diperbaiki, data pernikahan milik LZ tidak dapat di-entry ke SIMKAH berbasis Web, sehingga tidak dapat pula dicetak kartu nikahnya. Mengingat SIMKAH berbasis Desktop hanya mampu mencetak buku nikah saja, sebab tidak memiliki kemampuan untuk membuat barcode yang nantinya digunakan di kartu nikah. Kasus LZ tidak hanya dirasakan oleh dirinya sendiri, sebab saat itu server mengalami perbaikan selama 8 hari. Padahal pasangan yang melangsungkan pernikahannya di 8 hari tersebut berjumlah 22 pasangan. Oleh sebab itu, permasalahan demikian dapat menjadi masukan kepada Kemenag Pusat agar memberikan pengumuman bilamana hendak memperbaiki server. Sehingga para operator SIMKAH dapat segera bergegas mengantisipasi hal tersebut. 51 Ahmad Zainul Ma'arif, Wawancara, Gayungan, 23 Oktober 2019. 
di SIMKAH berbasis desktop. Sehingga MFA tidak perlu menunggu terlalu lama sampai datanya sudah benar-benar terhapus.52

Kelima, tentang hasil print out akta nikah dan buku nikah. Zainul selaku pihak yang diberi kewenngan untuk melakukan print kedua berkas itu, merasakan betul bahwa template yang dimiliki oleh SIMKAH berbasis web masih kurang memadai. Sehingga hasil print out-nya justru terlihat lebih rapi dari SIMKAH berbasis desktop.53 HY selaku pengantin perempuan yang mendapatkan buku nikah juga mengatakan tidak mau kalau harus beralih ke sistem yang baru, padahal sistem yang lama dapat mencetak lebih rapi. Oleh sebab itu, ia turut menyetujui adanya kebijakan terkait implementasi SIMKAH Ganda di KUA Gayungan.54

Dengan demikian, secara keseluruhan dapat ditarik menggunakan sudut pandang efektivitas hukum Friedman55, bahwa implementasi SIMKAH Ganda di KUA Gayungan disebabkan oleh struktur, substansi dan budaya hukum di KUA tersebut. Struktur hukum, yakni para penegak hukum yang dalam hal ini ialah Kepala KUA dan operator SIMKAH di KUA Gayungan, lebih mendukung dan memungkinkan bagi terlaksananya implementasi SIMKAH ganda daripada beralih sepenuhnya ke SIMKAH berbasis web.

Begitu pula dengan substansi hukum, yakni inti dari adanya aturan untuk menerapkan SIMKAH di KUA ialah untuk mengoptimalkan kinerja KUA dan memberikan aspek kemudahan dan kemanfaatan bagi masyarakat. Dengan begitu, implementasi SIMKAH Ganda dianggap mampu menjaga inti dari adanya aturan SIMKAH di KUA Kecamatan. Terakhir, terkait budaya hukum yang masih melekat ialah penerapan SIMKAH berbasis desktop yang lebih lengkap dan mampu memberikan kemudahan bagi pihak internal KUA maupun pihak eksternal masyarakat.

52 MFA, Wawancara, Gayungan, 23 Oktober 2019.

53 Ahmad Zainul Ma'arif, Wawancara, Gayungan, 28 Oktober 2019.

$54 \mathrm{HY}$, Wawancara, Gayungan, 28 Oktober 2019.

55 Lawrence M. Friedman berpandangan bahwa demi menjamin pelaksanaan hukum secara efektif, terdapat tiga faktor yang harus diperhatikan, yaitu struktur, substansi dan budaya hukum. Lihat Lawrence M. Friedman, The Legal System: A Social Science Perspective, (New York: Oxford University Press, 1947), 115. 


\section{Penutup}

Berdasarkan penjelasan di atas dapat ditarik beberapa kesimpulan sebagai berikut: pertama, implementasi SIMKAH ganda di KUA Gayungan Kota Surabaya dapat dinilai sebagai kebijakan strategis transformatif, karena database dapat dimiliki, bentuk antisipasi saat server diperbaiki, mengalami trouble atau penghapusan data yang terbilang lambat, mempermudah dalam pembuatan laporan, dan hasil print out lebih rapi. Kedua, secara struktur, substansi dan budaya hukum, implementasi SIMKAH berbasis web banyak menemui kendala, seperti penerapan SIMKAH ganda yang lebih mendapat dukungan, kebiasaan lama yang masih melekat, tidak adanya pengumuman saat server akan diperbaiki, serta kondisikondisi sosial yang tidak memungkinkan untuk beralih sepenuhnya ke SIMKAH berbasis Web.

\section{Daftar Pustaka}

Abdul Manan. Aneka Masalah Hukum Perdata Islam di Indonesia., Jakarta: Kencana, 2006.

Ade Putra Nanda. 'Analisa dan Perancangan Sistem Informasi Pengolahan Data Pernikahan pada Kantor Urusan Agama (KUA)', Jumal J-CLICK, Vol. 5 No. 1 Juli 2018, Padang: LPPM STMIK-Amik Jayanusa, 2018.

Agung Kurniawan. Transformasi Pelayananan Publik, Yogyakarta: Pembaharuan, 2005.

Barda Nawawi Arief. Kapita Selekta Hukum Pidana, Bandung: Citra Aditya Bakti, 2003.

Dumaria Manurung, Dedi Suhendro dan Lisa Andrianti Opusunggu, 'Perancangan Sistem Informasi Pencatatan Biaya Operasional pada KUA Kecamatan Tanah Jawa', Jurnal TECHSI, Vol. 11 No. 2 Juli 2019, Aceh: Fakultas Teknik Universitas Malikussaleh, 2019.

Ernita Dewi. 'Transformasi Sosial dan Nilai Agama', Jurnal Substantia, Vol. 14 No. 1 April 2012, Aceh: Fakultas Usuluddin UIN ar-Raniry, 2012.

Faiz Azkiya Arsyad. "Dampak Peraturan Pemerintah Nomor 48 Tahun 2014 terhadap Masyarakat dan Penghulu (Studi di 
KUA Gondokusuman dan Tegalrejo Yogyakarta)", Jurnal Al-Ahwäl, Vol. 10 No. 2 Desember 2017, Yogyakarta: Fak Syariah UIN Sunan Kali Jaga, 2017.

Lawrence M. Friedman. The Legal System: A Social Science Perspective, New York: Oxford University Press, 1947.

Nur Fadilah dan Titi Sriwahyuni. "Perancangan Aplikasi Layanan Administrasi Pernikahan Berbasis Web", Jurnal Voteknika, Vol. 7 No. 1 Maret 2019.

Soerjono Soekanto. Beberapa Aspek Sosial Yuridis Masyarakat, Bandung: Alumni, 1995.

Syamsurijal, 'Dialektika Regulasi dan Tradisi dalam Pelayanan Perkawinan di KUA', Jurnal SMaRT, Vol. 03 No. 02 Desember 2017, Semarang: Balai Penelitian dan Pengembangan Agama, 2017.

Tegar Setyo Pribadi, Taufik Baidawi dan Siti Marlina, 'Sistem Informasi Administrasi Nikah Berbasis Web pada KUA Bantar Gebang Bekasi', Prosiding SIMNASIPTEK, 2015, 110 Thobib Al-Asyar, SIMKAH Cara Baru Pelayanan Administrasi Nikah di Era Digital, dalam https://simbi.kemenag.go.id/pustaka/images/materibuku Lmakalah-islam-SIMKAH-cara-baru-pelayananadministrasi-nikah-di-era-digital.pdf. Diakses pada tanggal 2 Oktober 2019.

Wibawa, dkk, Analisis Kebijakan, Yogyakarta: UGM Press, 1999.

William N. Dunn. Analisis Kebijakan, diterjemahkan oleh Samodra Wibawa, dkk. Yogyakarta: UGM Press, 1999.

Dirjen Bimas Islam, Buku Panduan SIMKAH, dalam https://simbi.kemenag.go.id/pustaka/index.php/urusanagama-islam/kepenghuluan/622-buku-panduan-sisteminformasi-manajemen-nikah

Instruksi Dirjen Bimas Islam No. DJ.II-369 Tahun 2013, https://bimasislam.kemenag.go.id/pustaka/images/materi buku/instruksi.pdf.

Laporan Data Kependudukan KUA Gayungan Tahun 2019.

Peraturan Menteri Agama Republik Indonesia No. 19 Tahun 2018 tentang 
Ahmad Arif Masdar Hilmy dan Neila Sakinah: Implementasi......

https://bimasislam.kemenag.go.id/uploads/files/PMA\%2 52019.pdf.

Peraturan Menteri Agama Republik Indonesia No. 34 Tahun 2016 tentang Organisasi dan Tata Kerja Kantor Urusan Agama Kecamatan,

https://bimasislam.kemenag.go.id/uploads/files/PMA-34update.pdf.

Undang-Undang No. 1 Tahun 1974 tentang Perkawinan, https://kemenag.go.id/file/dokumen/UUPerkawinan.pdf.

Undang-Undang No. 24 Tahun 2013 tentang Perubahan atas UU

No. 23 Tahun 2006 tentang Administrasi Kependudukan, https://pih.kemlu.go.id/files/19.\%2520\%2520UU \%2520 NO $\% 252024$. 